\title{
Rethinking gastroesophageal reflux disorder
}

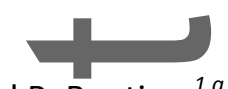

Samuel P. Banting, ${ }^{1, a}$ Henry E. Badgery, ${ }^{2, a}$ Matthew Read, ${ }^{2,3}$ and Hiroshi Mashimo ${ }^{4}$

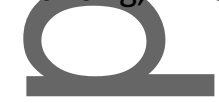

${ }^{1}$ Department of General Surgery, Royal Melbourne Hospital, Melbourne, Australia

${ }^{2}$ Department of Upper Gastrointestinal Surgery, St Vincent's Hospital Melbourne, Melbourne, Australia

${ }^{3}$ Department of Surgery, the University of Melbourne, St Vincent's Hospital, Melbourne, Australia

${ }^{4}$ Department of Medicine, VA Boston Healthcare System, Harvard Medical School

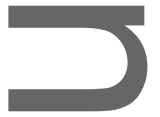

Address for correspondence: Hiroshi Mashimo, RES 151 VAMC/Harvard Medical School

1400 VFW Parkway, W Roxbury, MA 02132.hmashimo@hms.harvard.edu

Short title: Rethinking GERD
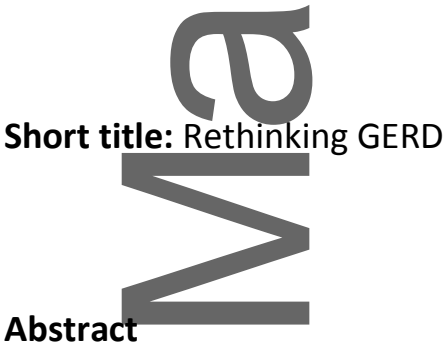

Gastroesophageal reflux disease (GERD) is a common clinical condition for which our understanding has evolved over the past decades. It is now considered a cluster of phenotypes with numerous anatomical and physiological abnormalities contributing to its pathophysiology. As such, it is important to first understand the underlying mechanism of the disease process for each patient

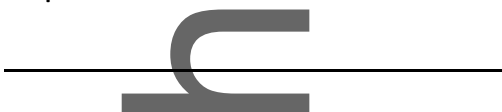

${ }^{a}$ These authors contributed equally to this article.

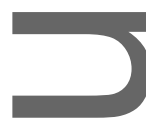

This is th auth $\mathrm{r}$ manuscript accepted for publication and has undergone full peer review but has not been througn copyediting, typesetting, pagination and proofreading process, which may lead to differences between this version and the Version of Record. Please cite this article as doi:

10.1111/nyas.14478.

This article is protected by copyright. All rights reserved. 
before embarking on therapeutic interventions. The aim of our paper is to highlight the mechanisms contributing to GERD and review investigations and interpretation of these results. Finally, the paper reviews the available treatment modalities for this condition, ranging from medical intervention, endoscopic options through to surgery and its various techniques.

Keywords: gastroesophageal reflux disease; fundoplication; hiatus hernia; lower esophageal sphincter

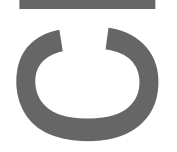

Introduction
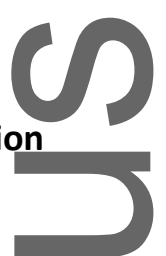

Gastroesophageal reflux disease (GERD) is a common condition affecting $13 \%$ of the population worldwide. ${ }^{1}$ It is defined by the American College of Gastroenterology (ACG) as symptoms or complications resulting from the reflux of gastric contents into the esophagus, oral cavity, or lungs. ${ }^{2}$ ${ }^{3}$ The clinical sequelae of GERD can be varied. Recurrent exposure of the esophagus to refluxate may lead to reflux esophagitis. Chronic exposure can also result in structural changes to the lower esophagus, including ulceration, peptic strictures, and intestinal-type metaplasia known as Barrett's esophagus (BE), which may represent a protective mechanism against acid injury. ${ }^{4-6}$ The underlying pathophysiology of GERD is complex with anatomical, functional, and neuromuscular factors all contributing to the disease process. Our understanding of this disease process is evolving and GERD is now increasingly referred to as a cluster of phenotypes as opposed to one distinct disease process. ${ }^{7}$ Given the inherent complexity of GERD, a proper diagnostic workup is important to optimize patient-specific treatment. A better understanding of GERD is important to avoid the inappropriate long-term use of proton pump inhibitors (PPIs) and inappropriate surgical interventions. The goal of therapy should be to address the underlying physiological and anatomical process responsible for the GERD, which differs from patient to patient. The aim of our article is to review the anatomical and pathophysiological mechanisms underpinning GERD and discuss how these relate to current diagnostic and treatment modalities.

This article is protected by copyright. All rights reserved. 


\section{Anatomy and pathophysiology of GERD}

The underlying pathophysiology of GERD is complex and multifactorial. Given the inherent heterogeneity of the disease process, ${ }^{7-10}$ a consensus definition for GERD has been difficult to attain. GERD is fundamentally a failure of the antireflux mechanisms that protect the esophagus from noxious gastric contents. ${ }^{11}$ These mechanisms include anatomical and physiological factors, both intrinsic and extrinsic to the esophagus. It may also be further confounded by other functional defects such as delayed gastric emptying, poor mucus and bicarbonate secretion, and esophageal chemical hypersensitivity. ${ }^{12}$ Furthermore, the more recently recognized brain-esophagus axis also influences the perception of heartburn through cognition, memory, and emotion is also thought to play a role in GERD, ${ }^{13}$ These factors are summarized in Table 1. Importantly, this list is not exhaustive with many factors overlapping and working in concert.

Intrinsic factors to the esophagus include the lower esophageal sphincter (LES) with its associated high-pressure zone, the presence of normal lining cells, and tight intercellular junctions that create a protective epithelial layer, and the secretion of mucus and bicarbonate from the submucosal glands. The LES is one of the main contributors to the antireflux mechanism that normally maintains a resting tone of $15-35 \mathrm{mmHg}$ and measures $2-4 \mathrm{~cm}$ in length at the distal esophagus just above the gastric folds. "It is made up of a composite of muscles rather than a simple continuous circular smooth muscle. It consists of an oblique arrangement of gastric muscle fibers on the left that become continuous with the lesser curve and an arrangement of clasp-like c-shaped esophageal smooth muscle cells on the right. Each set of musculature has distinct electrophysiological properties and are under separate nitrergic control. ${ }^{18}$ The upper segment of the LES lies at the level of the esophageal hiatus and the lower segment within the abdomen and is loosely fixed to the hiatus by the phrenoesophageal ligament (PEL). ${ }^{14}$

Extrinsic factors include the diaphragmatic sphincter, the presence of an intra-abdominal portion of the esophagus, the "angle of His," and the PEL. ${ }^{19}$ The diaphragmatic sphincter is formed by right crural fibers that wrap around the distal esophagus as it passes into the abdominal cavity, acting like a "pinchcock" clamp. The PEL is a layer of fascia that connects the gastroesophageal junction (GEJ) to the diaphragm and is important in maintaining the "angle of His" and an intra-abdominal length of the esophagus. The "angle of His" is the acute angle formed between the distal esophagus and gastric cardia. Such an angulation contributes to antireflux mechanisms by creating a flap valve

This article is protected by copyright. All rights reserved. 
effect. An intra-abdominal portion of the esophagus is also mechanically advantageous, as it exposes the distal esophagus to the positive pressure of the abdomen, as opposed to the negative pressure of the thorax. This leads to compression of the distal esophagus. Disruption to any of these mechanisms has the potential to lead to gastroesophageal reflux.

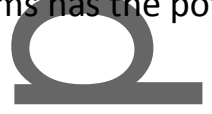

There are anumber of lifestyle factors that influence the pathophysiology of GERD. Caffeine, alcohol, nicotine, and many medications (e.g., benzodiazepines, calcium channel blockers, nitrates, B2 agonists, and xanthines) all contribute to GERD through relaxation of the LES. ${ }^{20-24}$ Dietary factors also contribute to GERD, including the size of meal and fat, protein and carbohydrate content leading to gastric distension, delayed emptying, and increased gastric content acidity, as well as the timing of meals.

Obesity has a significant role in the pathophysiology of GERD. Research from the Nurses' Health Study found a dose-dependent relationship between BMI and GERD. ${ }^{26,27}$ Furthermore, weight loss has been shown to decrease or completely resolve GERD symptoms. ${ }^{28}$ The mechanism underpinning the correlation between obesity and GERD are complex. Increased intra-abdominal pressure led to increased transdiaphragmatic pressure gradient (TPG) and slowed the esophageal transit time, leading to the development of reflux. ${ }^{29,30}$ This correlates specifically with central obesity rather than increasing BMI alone. ${ }^{31}$ There is an increased prevalence of hiatus hernia $(\mathrm{HH})$ in the obese population, occurring in nearly $40 \%$ of morbidly obese patients. ${ }^{32,33}$ The anatomical structure and barrier function of the LES is thereby impaired, as described earlier. ${ }^{34}$ Obesity also leads to an increase in transient lower esophageal relaxation (tLESR) episodes, leading to GERD. ${ }^{35}$ This may be partly explained by diet whereby excessive fat consumption promotes secretin and cholecystokinin secretion, which, in turn, stimulates LES relaxation. ${ }^{36,37}$ Obstructive sleep apnea (OSA) is commonly associated with obesity and is hypothesized to contribute to the pathophysiology of GERD. One study reported that $75 \%$ of patients with OSA experience nocturnal reflux as compared with $14 \%$ of the U.S. population. ${ }^{38}$ This is thought to occur through increased intra-abdominal pressure and decreased intrathoracic pressure during inspiratory efforts in apnoeic episodes. This increases the TPG and disrupts the LES, which leads to reflux. ${ }^{39}$ Adipokines have also been implicated in GERD. Increased leptin levels have an association with clinical GERD severity, ${ }^{40}$ whereas ghrelin levels have an inverse relationship with GERD. ${ }^{41}$ The mechanism underpinning the association between obesity 
and GERD is complex and multifactorial, working in concert, increasing the TPG, and impairing acid clearance from the esophageal lumen.

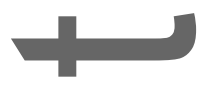

The key noxious contents of duodenoesophageal reflux include acid, pepsin, and bile. By disturbing the local $\mathrm{pH}$-ion balance, acid has a direct injurious effect on the epithelium. It also acts indirectly by activating pepsin, a proteolytic enzyme, from pepsinogen, leading to an impaired mucosal barrier. By contrast, bile canpass directly into cells and disrupt cellular function by virtue of its lipophilic properties. ${ }^{3}$ All of these processes eventually lead to tissue injury and the ensuing inflammatory response. The failure of esophageal barrier function and esophageal permeability is critical in the pathogenesis of mucosal damage from noxious refluxate. ${ }^{16}$

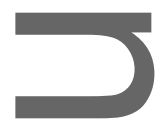

Reflux events are thought to occur through four mechanisms: tLESR, low LES pressure, swallowassociated LES relaxation, and low LES pressure associated with increased intra-abdominal pressure or straining. ${ }^{16}$ The degree to which the intrinsic and extrinsic protective factors contribute to reflux differs depending upon the mechanism and physiological conditions.

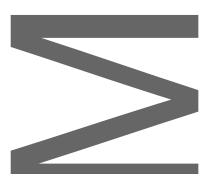

tLESR underlies $90 \%$ of GERD in patients without structural defects at the GEJ. ${ }^{16} \mathrm{It}$ is defined as LESR occurring independently to swallowing, not accompanied by peristalsis, accompanied by diaphragmatic inhibition, and persisting for longer than the swallow-induced LES relaxation $(>10 \mathrm{~s}){ }^{14}$ ${ }^{42}$ The dominant stimulus is distension of the proximal stomach and is thought to be a vagally mediated mechanism to vent gas. ${ }^{16}$ There is also evidence to suggest that axial stretch of the esophagus also causes LES relaxation. ${ }^{43}$ Animal studies have highlighted the role of nitric oxide in the control of LES continence, mainly through the neurogenic response of neuronal nitric oxide synthase (nNOS). ${ }^{15,44}$ Activation of gamma-aminobutyric acid (GABA) receptors inhibit tLESRs. ${ }^{45}$ As such, tLESRs are an important therapeutic target in the management of GERD.

The contribution of the gastroesophageal flap valve or the "Hill flap" valve to antireflux mechanisms is important but often underrecognized. ${ }^{46}$ It is formed by the intraluminal extension of the angle of 
His that abuts the lesser curve of the stomach and creates a flap valve allowing the one-way passage of food, as outlined in Table $2 .{ }^{47}$ Impairment of this flap has been associated with GERD, poor response to PPI therapy, $\mathrm{HH}$, and lower LES pressure. ${ }^{47-50}$ Despite its importance, it is often underreported or without a properly retroflexed endoscopic examination of the insufflated stomach. $^{50}$

The presence of $\mathrm{HH}$ is an important contributor to the etiology of GERD. One study has found that despite not all patients with $\mathrm{HH}$ having symptoms of GERD, up to $94 \%$ of patients with reflux esophagitis have $\mathrm{HH}{ }^{52}$ Furthermore, the $\mathrm{HH}$ size has also been shown to correspond with GERD symptoms with large herniae associated with abnormal pH monitoring, however, a small $\mathrm{HH}$ are poor predictors of GERD symptoms. ${ }^{53}$ When the proximal stomach and abdominal esophagus herniate into the thoracic cavity, there is a separation of the LES with the crural diaphragm that shortens the high-pressure segment and impairs sphincteric function. ${ }^{14}$ Additionally, migration of the GEJ into the thoracic cavity leads to an increased pressure gradient during inspiration and subsequent LES relaxation due to negative intrathoracic pressure. ${ }^{14}$

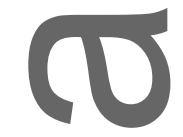

Another mechanism that contributes to GERD, particularly in the presence of $\mathrm{HH}$, is the postprandial acid pocket. The acid pocket is a normal physiological response following the ingestion of food. Following the secretion of acid from gastric parietal cells, excess acid rises and sits above the food bolus forming a "pocket." This acid pocket sits in the proximal stomach adjacent to the GEJ and can lead to reflux during periods of low LES pressure. ${ }^{14,16,54}$ Evidence suggests that the location of the acid pocket relative to the diaphragm influences the development of GERD. In the presence of $\mathrm{HH}$, the acid pocket represents a major risk factor for GERD. As it sits above the diaphragm, it is subjected to negative pressure during inspiration. In combination with tLESRs, reflux ensues. ${ }^{55}$

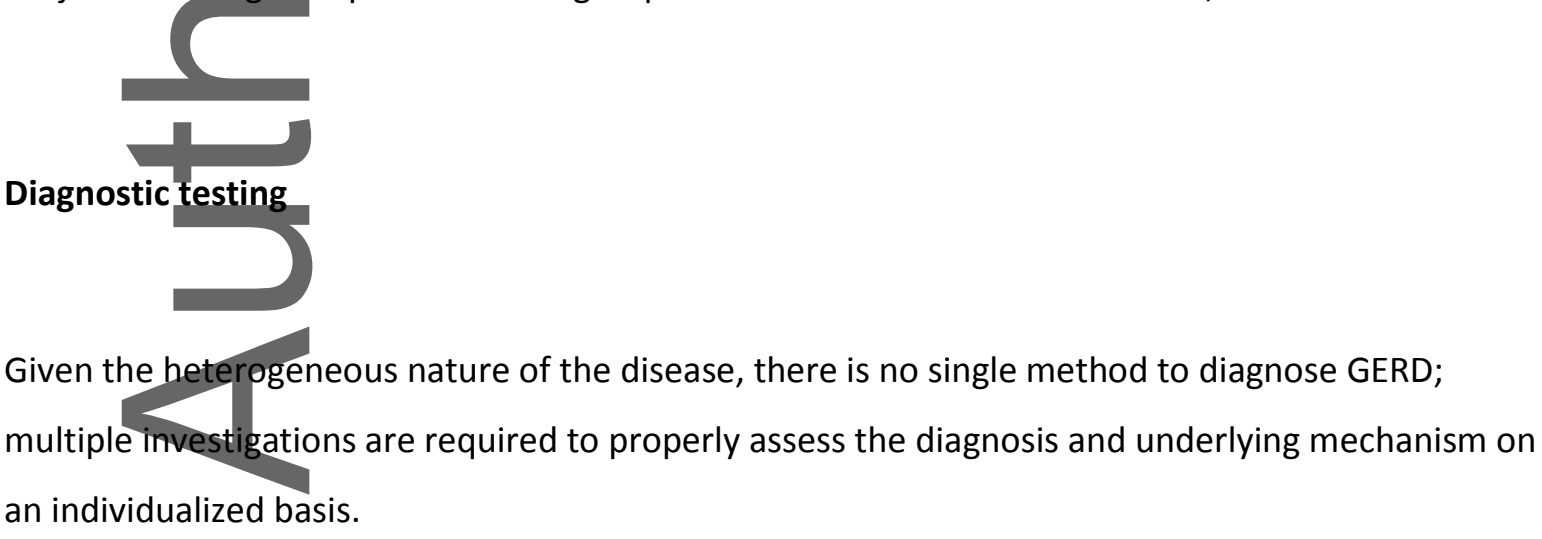

This article is protected by copyright. All rights reserved. 
The first step in making a diagnosis of GERD is to elicit a clinical history and perform a physical examination of the patient. Importantly, a significant number of patients with PPI-refractory GERD will have a significant improvement in their symptoms if given explicit instructions to take their prescribed PPI 30-45 min before breakfast. ${ }^{56}$ The best efficacy of PPIs has been shown to be in the morning when generally the optimal number of proton pumps can be blocked after a period of fasting. Furthermore, for patients that are suffering from predominately nocturnal symptoms, a twice-daily regimen of PPIs has been shown to be more effective than the morning dose alone. ${ }^{57}$ In addition to being a treatment modality, the use of PPI has also been advocated as the first step and most cost-effective means of diagnosing GERD. ${ }^{58,59}$

\section{()}

Traditionally, upper gastrointestinal (GI) endoscopy has been considered as an important adjunct in both the diagnosis of GERD and its associated complications. Despite being an invasive procedure, it enables visual inspection of the lower esophagus, histopathological assessment of the tissues, and dynamic assessment of the Hill flap valve mentioned above (Table 2). ${ }^{2}$ This is demonstrated with a retroflexed gastroscope with gastric insufflation and is graded from I to IV according to the prominence of the ridge and its apposition with the gastroscope. ${ }^{46}$ This is a dynamic endoscopic maneuver to assess the valve, particularly functionally with gastric distension, and also assesses the presence of $\mathrm{HH}$. This has a greater sensitivity than standard radiological investigations that may be unable to provide this dynamic assessment without the use of effervescent tablets and exerting external abdominal pressure (and perhaps the Valsalva maneuver) during the exam. Grades I to II are considered physiological whereas grade III and IV are abnormal and associated with GERD with grade IV implying the existence of $\mathrm{HH}{ }^{46}$ The Hill flap valve is demonstrated to be highly reproducible on endoscopy and assist in the diagnosis of GERD. ${ }^{60}$ The assessment of the length and width of the $\mathrm{HH}$ is important, as hernias greater than $2 \mathrm{~cm}$ are not amenable to endoscopic management. Moreover, insufflation may reveal previously unrecognized paraesophageal or mixed hernias that may be responsible for dysphagia or postprandial dyspepsia.

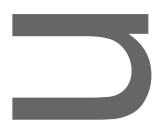

The importance of adequate assessment of the Hill grade is a key step in the endoscopic examination of a patient with suspected GERD. The Hill flap valve is predictive of failure of PPI therapy. One study examining PPI response found in patients with symptomatic GERD and Hill flap 
valve found of those who responded to 4 weeks of PPI therapy, $77.1 \%$ were grade I to II and $22.9 \%$ were grade III to IV. These numbers were similar after 8 weeks of PPI therapy. ${ }^{49}$ Given the presence of abnormalities in the Hill flap valve is predictive of failure of PPI therapy, assessment should be routine in patients undergoing endoscopy for GERD symptoms. If Hill grading suggests pathology, prompt consideration of therapy to correct anatomy should be considered to improve defensive mechanisms of the GEJ. To persist with long-term PPIs in these patients is likely futile and puts the patient at risk of long-term side effects associated with PPIs. ${ }^{47,49}$

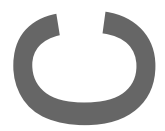

Routine biopsies are not recommended in the diagnosis of GERD. ${ }^{2}$ Erosive esophagitis is only present in about one-third of untreated patients and is an uncommon finding in those already trialed on PPI therapy. In patients with symptomatic GERD, 70\% will have the normal esophageal mucosa. Of those already on a PPI, $90 \%$ will have a normal endoscopic examination. ${ }^{9}$ Random esophageal biopsies are not useful in diagnosing GERD, although they are useful at tracking resolution of disease complications, such as Barrett's and esophagitis or ruling out eosinophilic esophagitis in patients with heartburn on dysphagia, as an alternative diagnosis to peptic disease and strictures. Endoscopy is an important investigation in identifying complications or anatomical pathology predisposing to GERD, however, is not able to make a conclusive diagnosis of GERD itself. ${ }^{9}$

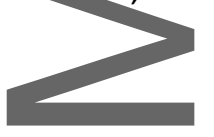

There are several other key aspects of the upper endoscopy that need to be considered when examining the dyspeptic patient. These mostly involve the exclusion of other pathologies that can mimic GERD. These include reporting the presence of bile in the stomach, assessment for Helicobacter pylorinfection and associated gastritis, retained food, which is common in gastroparesis in a properly fasted patient, the presence or absence of antral peristaltic waves, and the appearance of the pyloric sphincter (wide gaping with bile refluxate, for instance, may suggest the additional need of sucralfate or bile acid binders, but negate the role of botox in a patient later found to have gastroparesis) ${ }^{61}$ Bile acid reflux appears to be associated with the development of Barrett's metaplasia and carcinogenesis as well as triggering GERD symptoms through inflammatory stimulation and oxidative stress. ${ }^{62}$ Helicobacter Pylori is significant as the presence is associated with a greater acid-reducing effect of PPI therapy. ${ }^{63}$ Furthermore, there is a protective association between $H$. pylori and reflux though this is thought to be correlative rather than causative. ${ }^{64,65}$ 
The gold standard for objective diagnosis of GERD is ambulatory $\mathrm{pH}$ monitoring performed while off acid-suppressing medications ${ }^{66}$ while studies performed on medications are suited to address their treatment efficacy. $\mathrm{pH}$ monitoring is used in the assessment of the refluxate entering the lower esophagus. Both the timing of the $\mathrm{pH}$ changes and the duration of acid exposure are important assessments. The $\mathrm{pH}$ tracings should be reviewed to confirm that the probe had not migrated into the stomach during the study and that meals and supine periods are properly labeled. Esophageal acidification is quantified using the DeMeester score and acid exposure time (AET). ${ }^{67}$ Making a distinction between the reflux occurring when the patient is in the supine and erect positions may provide important insight. Accurate recording of the meal times and periods of supination is important as standard meal times are excluded from the analysis. In the supine position, the intraabdominal pressures are higher and, as such, also the risk of reflux. However, predominant reflux during the erect position suggests that the natural defensive mechanisms at the GEJ are not effective. Thus, patients are advised to remain in the upright position during waking hours of the recording. As a further adjunct to this investigation, impedance testing can be used to identify the presence of reflux of any type. Impedance monitoring improves the assessment of the reflux to symptom association, helping to distinguish between functional heartburn and NERD or the acidsensitive esophagus. ${ }^{68}$ Three indices are used to quantify the relationship between reflux and symptoms, namely the symptom association probability (SAP), symptom index (SI), and the symptom sensitivity index (SSI). ${ }^{69}$

A potentiallimitation of this test is the alteration of the natural physiology of the esophagus by having an electrode within the lumen of the esophagus or traversing the GEJ with a dual-channel probe and, as such, may alter the underlying physiology of the patient. Also, some refluxate may not be acidic yet still predisposing patients to symptoms as discussed above. As such, an impedance-pH study is generally favored to assess the role of volume reflux and correlation with symptoms. A dualchannel probe is also helpful in ascertaining that the patient has been compliant in withholding PPIs and $\mathrm{H}$-blockers for a week before the study or even revealing achlorhydria in patients with atrophic gastritis, for example.

Importantly, those patients with a negative DeMeester score but positive SAP on the impedance study, are experiencing nonacidic GERD. This cohort of patients have been shown to benefit most 
from sucralfate or bile acid binders or surgical intervention as their symptoms are independent of acid and as such will have little benefit to PPI therapy. ${ }^{56}$

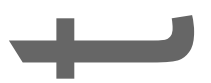

Given the importance of the LES in the pathology of GERD, it is necessary to consider the role of manometry in the assessment of this condition. Given that there has been a discordance between the traditional interpretation and the current literature about LES, the role of manometry as an investigation has also evolved. The Chicago Classification of esophageal motility uses algorithms to analyze high-resolution manometry (HRM) and was first published in 2009. The International HighResolution Manometry Working Group has since made updates in 2012 and 2014..$^{70,71}$

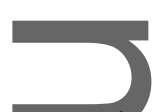

Earlier manometric classifications focused only on achalasia, EGJ outlet obstruction, motility disorders, and abnormalities. In the revised classification in 2014, however, the emphasis was placed on EGJ resting pressure morphology and contractility. In addition, the concept of the distal contractile integra/ (DCl) for defining hypo- and hypercontractility has also been highlighted. As a result of this improved understanding, patients previously thought to have motility disorders have been reclassified as having small $\mathrm{HH}$ and transient esophageal shortening. ${ }^{70,72}$

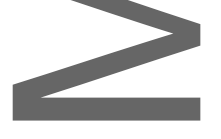

The HRM Working Group has also recently acknowledged the importance of the LES and its role in GERD. In their recent guidelines, they have classified EGJ morphology into three subtypes, which are based on an assessment of the manometric values of the crural diaphragm and the LES. This also assesses the anatomical relationship of the two pressures. In particular, the working group highlights the important physiological role this has in GERD and stresses the importance of its reporting on manometry results. The significance of this illustrates the evolving understanding of the pathophysiology of GERD and the role that manometry has in making a diagnosis and understanding of the particular underlying pathophysiology. ${ }^{70}$

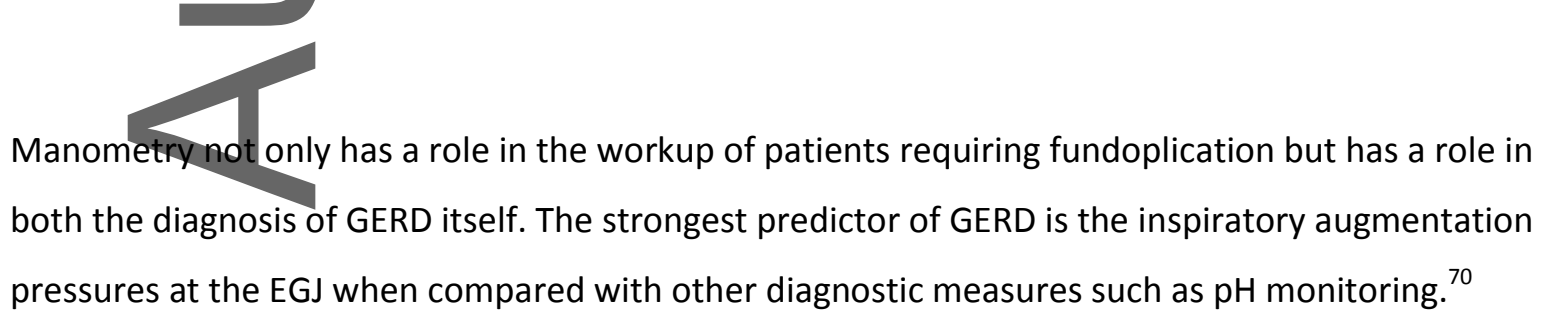
This article is protected by copyright. All rights reserved. 
Furthermore, the $\mathrm{DCl}$ has been shown to be elevated in patients with manometric proven GERD. This is also essential in ruling out primary motility disorders of the esophagus, including achalasia which frequently presents with heartburn (13 to $68 \%$ of cases) and would largely contraindicate traditional Nissen, for example. ${ }^{73}$ It may also reveal underlying systemic sclerosis that can present without overt cutaneous manifestations but may explain pulmonary findings previously attributed to GERD alone. ${ }^{74}$ Historically, a barium esophagogram has been used to assess patients with esophageal reflux. They have poor sensitivity and specificity, however, compared with more modern assessments. ${ }^{75,76}$ Although they can provide important anatomical information and structural abnormalities (e.g., strictures, hiatal hernia size, and diverticulum) and can be useful preoperatively, they have been largely phased out and are not recommended in the ACG guidelines in the diagnosis of GERD. ${ }^{2}$ Nuclear medicine studies are an important adjunct to the assessment of GERD, as they allow for the diagnosis of other pathologies that may mimic GERD, such as delayed gastric emptying. More recently, this has also been evaluated using a SmartPill ${ }^{\mathrm{TM}}$ (Medtronic, Fridley, MN, USA), ${ }^{77}$ or the 13-C Gastric Emptying Breath Test (Cairn Diagnostics, Franklin, TN, USA). ${ }^{78}$ Such distinctions are important to make, as they are associated with different pathophysiological processes and require different management.

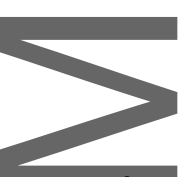

\section{Assessment tools and therapeutic options}

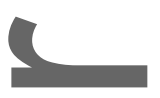

The existing literature of antireflux therapy comparing the success of different antireflux treatments is largely qualitative and fails to assess the underlying process that is targeted by each treatment. Assessment of success typically relies on the resolution of heartburn symptoms, absence of complications (belching, gas bloat, and dysphagia), and no ongoing PPI requirement. In addition to symptomatic assessment, qualitative questionnaires such as the REFLUX questionnaire that incorporate health-related quality of life with reflux symptoms and the Visick score are also used to assess the success of intervention. ${ }^{79}$ These are primarily used as research tools with limited clinical application.

This article is protected by copyright. All rights reserved. 
The therapeutic options for the treatment of GERD are broad and include antireflux surgery, medical therapy, lifestyle modification, and both novel surgical and endoscopic adjuncts. Traditionally, the treatment of GERD relied upon a stepwise approach from lifestyle modification to medical therapy to surgery. ${ }^{80}$ However, given the variation in the underlying pathophysiology and mechanism of action of existing therapies, treatment should be targeted and guided by thorough investigations and postintervention evaluation. ${ }^{81}$ These are summarized in Table 3.

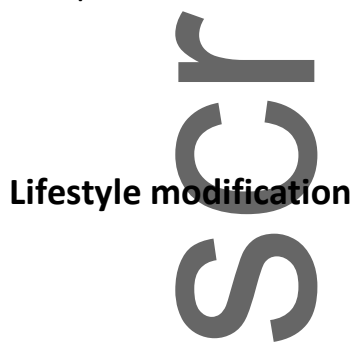

Lifestyle modification aims to minimize risk factors for symptomatic GERD, such as dietary modification, bed head elevation, minimizing alcohol intake, avoiding certain drugs, smoking cessation, minimizing caffeine, and weight loss. ${ }^{82,83}$ While these measures are recommended for all patients with GERD, particularly at initial presentation, there is a minimal or variable effect on patient symptoms and should be an adjunct to surgical and/or medical therapy. ${ }^{79,83-85}$

\section{Medical therapy}

Acid suppression with PPIs is the mainstay of the medical management of GERD and acts through the irreversible blockade of $\mathrm{H}^{+} \mathrm{K}^{+}$-ATPase proton pumps within the parietal cells of the stomach. ${ }^{85} \mathrm{Up}$ to $30 \%$ of patients fail to respond to PPI therapy either partially or completely. ${ }^{86}$ PPIs are effective in reducing acid reflux and the volume of gastric secretions to an extent however nonacidic reflux remains an issue. ${ }^{87} \mathrm{PPIs}$ also do not address the underlying anatomic and neuromuscular causes for GERD. ${ }^{79}$ Furthermore, PPIs have an effect on bile acids and other enzymatic secretions from the duodenum that are associated with nonacidic reflux and $\mathrm{BE} .{ }^{16} \mathrm{As}$ acid is required in the cleavage of proenzymes to enzymes, an absence of acid may affect gastric content and flow. ${ }^{88}$ Clear instructions for timing and medication compliance is critical to the success of PPI therapy; it must be taken 30-45 min prior to the first meal of the day with the addition of a second dose if required. ${ }^{89}$ In one major randomized trial examining PPI refractory GERD, $11 \%$ of patients with PPI refractory heartburn had resolution of symptoms after a 2 -week trial of omeprazole twice-daily under strict instruction. ${ }^{56}$ 
Although there have also been concerns regarding side effects of long-term PPI use based on population studies, including malabsorption, osteoporosis, dementia, and both $\mathrm{Gl}$ and pulmonary infections, the evidence for these side effects is weak and lacks rigorous long-term data. ${ }^{90,91}$ Another consideration with the use of PPIs is the interaction with other medications. In some studies, it has been suggested that PPIs block the conversion of the prodrug clopidogrel to its active form by preferentially utilizing the cytochrome P450 enzymes within the liver. ${ }^{92,93}$ A more recent metaanalysis, however, has shown that the use of PPIs and dual antiplatelet therapy improves outcomes of GI bleeding, without compromising cardiovascular outcomes and that further randomized trials are required in this area. ${ }^{94}$

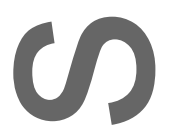

There are numerous alternatives to PPIs that have been trialed with various degrees of success. Histamine 2 receptor antagonists $\left(\mathrm{H}_{2} \mathrm{RA}\right)$, such as ranitidine, nizatidine, famotidine, and cimetidine, although historically the first-line therapy, are less effective than PPIs in symptom control and esophagealhealing and are often used as the step-down therapy or as an adjunct to PPIs. They work through reversible blockade of histamine 2 receptors of the parietal cells in the stomach thereby decreasing acid secretion. ${ }^{95}$ Some trials have demonstrated an initial response to combination therapy of twice-daily PPI and $\mathrm{H}_{2} \mathrm{RA}$ reduces the incidence of nocturnal acid breakthrough; however, the clinical effectlasted approximately 1 week and had no long-term benefit due to tolerance to the $\mathrm{H}_{2} \mathrm{RA}^{96}$

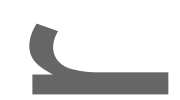

Alginates, derivatives of alginic acid derivates, are a further pharmacological option in the treatment of GERD. They have been demonstrated to colocalize with the acid pocket, either displacing or neutralizing it and, as such, increasing the $\mathrm{pH}$ of the postprandial refluxate. ${ }^{97} \mathrm{~A}$ further mechanism has alsa been proposed by forming a barrier to reflux through molecular cross-linking and formation of a cap over the gastric contents, as such has been shown to reduce the number of reflux episodes. ${ }^{98}$ A recent systematic review and meta-analysis by Leiman and colleagues found that alginates are more effective than placebos or antacids, however appear to be less effective than PPIs and $\mathrm{H}_{2} \mathrm{RA}$, although not statistically significant. ${ }^{99} \mathrm{~A}$ call for further research in assessing these medications in combination is warranted.

This article is protected by copyright. All rights reserved. 
Baclofen, a GABA agonist is effective in reducing reflux events and GERD symptoms through the reduction of tLESRs as well as increasing the postprandial LES tone. The role of the stretch receptors in the fundus is also a mechanism being explored with the use of GABA agonists to aid in increased LES tone. However, its use is limited by central side effects including dizziness and somnolence. 100, 101 Eurthermore, the long-term efficacy has not been demonstrated. ${ }^{102}$ There are several emerging therapeutic agents that show promise in the treatment of GERD. Colesevelam (IW3718), a novel bile acid sequestrant has been shown to reduce heartburn and regurgitation symptoms when taken with PPI in a recent randomized controlled trial. ${ }^{103}$ It is currently entering phase III trials. There is also emerging evidence on the use of acid-sensing ion channel inhibitors to improve heartburn symptoms by reducing esophageal hyperalgesia. ${ }^{104}$ Antacid medications are commonly used in the management of intermittent heartburn symptoms however they do not provide long-term symptomatic relief nor do they heal esophagitis, prevent complications, or address the underlying cause of GERD. ${ }^{85}$

\section{Surgical management}

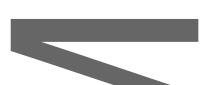

There is an important distinction between surgery for GERD and $\mathrm{HH}$, although the two surgeries are often performed inconjunction. In the case of $\mathrm{HH}$, surgery aims to restore the normal anatomical configuration by returning the stomach from the thorax into its native position and closing the hiatal defect. Given the contribution of HH in GERD, the repair will help treat and prevent reflux. By contrast, the fundoplication is primarily an antireflux procedure. However, given the correlation between $\mathrm{HH}$ and PPI refractory GERD, $\mathrm{HH}$ repair and fundoplication are frequently performed together. Furthermore, a fundoplication reduces the risk of $\mathrm{HH}$ recurrence by buttressing the crural repair with the fundic wrap. ${ }^{105}$

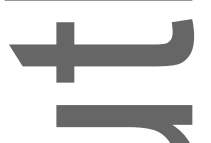

For patients with GERD in the absence of $\mathrm{HH}$, laparoscopic fundoplication is the gold standard operation and mainstay of antireflux surgery. ${ }^{5}$ Fundoplication has been demonstrated to be efficacious and durable in treating GERD with persistent symptomatic relief demonstrated in $90 \%$ of patients at 10 years. ${ }^{5,106}$ Patients with the best overall outcomes from antireflux surgery are those who have typical GERD symptoms and are responding to PPI therapy in addition to a prolonged AET 
$\left(\mathrm{pH}<4,>12 \%\right.$ of the time).$^{81}$ The LOTUS trial, which published its final outcomes in 2011, supports this demonstrating that patients with a complete response to PPIs have a high overall remission rate with either long-term PPI use or antireflux surgery. ${ }^{106}$ Furthermore, it should be noted that patients with atypical symptoms and those not responding to PPIs need very careful assessment (ie: with $\mathrm{pH} /$ impedance monitoring both whilst taking and not taking PPIs) before considering surgical intervention. As such, despite surgery being an effective treatment modality for GERD, a careful assessment of the patient's symptoms and workup is required to isolate the patients who are best suited to this treatment modality.

The internationalconsensus regarding preoperative examinations and clinical characteristics assessment to select adult patients for antireflux surgery (ICARUS) published their guidelines in August 2019. As well as emphasizing the above, they have highlighted that endoscopy, oesophageal manometry (to rule out major motor disorders), and esophageal pH monitoring (+/-impendence testing) are mandatory assessment tools prior to antireflux surgery. Furthermore, patients with a large $\mathrm{HH}$ should be assessed with barium swallow preoperatively to assess the length of the esophagus .

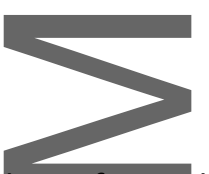

Currently performed procedures include the Nissen fundoplication consisting of a $360^{\circ}$ wrap and partial fundoplications. These include both the Toupet fundoplication, consisting of a posterior $270^{\circ}$ posterior wrap and the Dor, which consists of an anterior $180^{\circ}$ wrap. Worldwide, the Nissen fundoplication is the most commonly performed procedure and has been shown to have superior durability. However, it has been demonstrated to have a higher side effect rate compared with partial fundoplications, notably dysphagia (8-12) and gas bloating symptoms (19\%). ${ }^{108,109}$

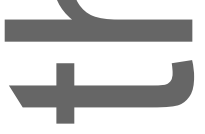

The augmentation of the stretch receptors in the fundus and inhibition of vagal tone may increase the resting pressure at the LES. Fundoplication utilizes this by stretching the fundus to form part of the wrap, as such utilizing both anatomical and physiological mechanisms to improve patient outcomes. Unfortunately, magnetic sphincter augmentation (MSA) devices are not able to use this 
mechanism to reestablish increased basal tones at the LES, rather utilizes extrinsic compression from the device itself.

Antireflux surgery is pursued in three settings: where long-term definitive management of GERD is desirable over indefinite use of PPI, where there is persistent reflux disease despite maximal medical therapy and where there is structural alteration at the GEJ. Further to this last setting, in the case of a large $\mathrm{HH}$, surgery allows for repositioning of the LES to the level of the diaphragm. ${ }^{85}$ Fundoplication works through a number of mechanisms. Anatomical antireflux mechanisms are restored through the repair of any $\mathrm{HH}$ and the realignment of the LES with the crural sling, the restoration of the intraabdominal esophageal segment, the recreation of the esophageal Hill flap valve and the angle of HIS as well as further mechanical compression of the distal esophageal and increased basal LES pressure. ${ }^{43,110}$ Fundoplication also has a physiological mechanism with evidence suggesting it reduces transient LES relaxation by reducing axial stretch fibers at the LES and altering fundic tone, thereby minimizing LES relaxation. ${ }^{43}$

Despite the developments of new techniques, and in keeping with our developing understanding of GERD pathogenesis, fundoplication remains an appropriate tool in the management of GERD in the correct circumstances. In the presence of $\mathrm{HH}$, in many cases, this anatomic defect needs to be repaired atongside a fundoplication as an antireflux procedure. As mentioned above, once hernias are greater than $2 \mathrm{~cm}$, they are not amenable to the endoscopic technique. The success of the fundoplication and assessment of the basal pressures at the LES can be difficult to appreciate at the time of operation. Commonly, the wrap is made around a bougie to ensure adequate laxity to prevent dysphagia and a tactile judgment is made to ensure it is adequately tight. Given the multitude of factors contributing to the GEJ antireflux mechanism, in particular, the active basal tone of the LES, the intraoperative subjective assessment of wrap tightness cannot predict the success of the fundoplication. It is not possible to assess objectively the likely outcome of a fundoplication intraoperatively. Surgeons rely to an extent upon tactile feedback in determining the appropriate tightness of a wrap, however, this is limited with the use of laparoscopic surgery. Furthermore, the closure of the crura around the esophagus relies on the esophageal diameter as a guide. In instances of a dilated esophagus, closure of the crura may still leave a large and clinically significant defect despite having a tight appearance. There is evidence that postoperative on-table endoscopy can reduce the rate of dysphagia through addressing excessive esophageal narrowing but it is not shown to improve the success from an antireflux point of view. ${ }^{111}$ New endoscopic devices such as

This article is protected by copyright. All rights reserved. 
EndoFLIP ${ }^{\circledR}$ (Crospon Ltd., Dangan, Galway, Ireland) may be used to determine these pressures intraoperatively and trials are ongoing to determine its clinical application. ${ }^{112}$

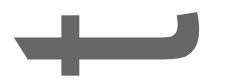

In addition to its association with reflux disease, obesity is also a strong risk factor for the failure of laparoscopic antireflux surgery with one meta-analysis finding a $53 \%$ increased risk over nonobese patients. ${ }^{113}$ This has driven the use of Roux-en-Y gastric bypass (RYGB) for patients with a BMI > 35 and GERD with favorable outcomes over fundoplication demonstrated in the literature. ${ }^{114-116}$ RYGB has a different antireflux mechanism to fundoplication. The creation of a small proximal gastric pouch separates the majority of the acid-producing stomach from the distal esophagus and the creation of a Roux-en-Y reconstruction of the small bowel prevents the reflux of bile into the distal esophagus. ${ }^{115}$ The treatment of obesity also leads to an overall decrease in intra-abdominal pressure, a known risk factor for GERD.

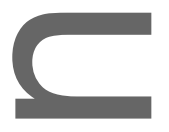

\section{Novel surgical alternatives}

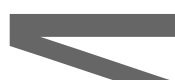

LINX ${ }^{\circledast}$ Reflux Management System (Torax Medical, Shoreview, MN, USA) magnetic sphincter augmentation (MSA) is a novel therapy in the treatment of GERD whereby a chain of interconnected magnetic beads is laparoscopically inserted around the distal esophagus to create a dynamic circumferential pressure around the LES, thereby allowing the passage of food boluses but providing enough pressure to prevent the reflux of gastric contents. ${ }^{115,117}$ Furthermore, it allows patients to retain the ability to belch and vomit with less gas bloating. It was designed to address a therapy gap for patients with disease inadequately controlled by medical therapy who did not want to undergo a fundoplication with its associated side effects and is easily reversible if needed. ${ }^{118}$ The LINX ${ }^{\circledR}$ MSA system provides $15-25 \mathrm{mmHg}$ pressure at the LES that exceeds gastric pressures $(5-10 \mathrm{mmHg}$ ) but is easily overcome by peristaltic pressure $(35-80 \mathrm{mmHg}) \cdot{ }^{117,119} \mathrm{MSA}$ leads to a similar improvement in HR-QOL scores when compared with fundoplication surgery and has been demonstrated to be safe and reversible and is associated with fewer side effects. ${ }^{120}$ The LINX ${ }^{\circledR}$ system can lead to esophageal erosion or formation of a fibrotic capsule around the ring, leading to dysphagia. ${ }^{121}$ Importantly, the MSA does not restore anatomy at the GEJ. It is, therefore, unlikely to be useful in the presence of an anatomical disruption, such as $\mathrm{HH}$, or significant esophageal dysmotility. ${ }^{122}$ Low basal LES tone, 
identified on manometry studies in the presence of normal hiatal anatomy, may be aided by the insertion of MSA.

Electrical neuromodulation is another emerging antireflux therapy. The EndoStim ${ }^{\circledR}$ (EndoStim BV, Nijmegen, the Netherlands) treats GERD through augmentation of the LES using two electrodes placed at the LES controlled by a pulse generator implanted in the abdominal wall. ${ }^{123} \mathrm{It}$ is associated with a reduction in distal esophageal acid exposure time with a minimal side effect profile. ${ }^{124}$

\section{Endoscopic therapy}

While many endoscopic techniques have been developed and trialed, there are currently two that are presently available. These include radiofrequency (RF) treatment at the GEJ namely Stretta (Mederi Therapeutics, Greenwich, CT, USA), ${ }^{125-127}$ and Transoral Incisionless Fundoplication (TIF). ${ }^{128}$ $\mathrm{RF}$ involves delivering energy to the region of the LES to evoke muscular hypertrophy. This prevents GERD by increasing lower esophageal wall thickness and LES pressure and minimizing tLESRs. It is as effective as PPIs in reducing GERD symptoms short term, ${ }^{125}$ however has been shown in a number of studies withobjective outcomes such as AET do not reduce acid exposure. It has been hypothesized that this is due to the ablation of the sensory nerves in the distal esophagus during the procedure. ${ }^{129}$ Despite this, a 10-year follow-up study showed durability of results and a favorable costeffectiveness compared with PPI therapy. ${ }^{130,131}$

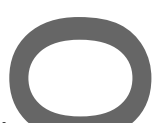

TIF works by creating an anatomic barrier at the GEJ by restoring the angle of His through the endoscopic placement of either sutures or staples. ${ }^{128}$ Compared with RF treatment, it is a technically difficult procedure, performed in the operating theatre and carries a risk of perforation and is associated with poor durability. Studies have shown the procedure to be associated with $80 \%$ PPI dependence at 4 years and a $64 \%$ treatment failure rate. ${ }^{132}$ While the literature demonstrates these to be effective in subjective measures, they have not demonstrated improvement in objective measures, such as esophageal acid exposure. ${ }^{133}$ 
The Medigus Ultrasonic Surgical Endostapler (MUSE) device (MediGus Ltd, Omer, Israel) is an endoscopic procedure designed to perform a partial fundoplication. This uses ultrasound guidance to staple the gastric mucosa to the intraabdominal esophagus and recreate the angle of His. This procedure is limited to patients with HHs less than two $\mathrm{cm}$ and Hill Grade I/II only. ${ }^{134}$

The role $\mathrm{OfRF}$, TIF, and MUSE are controversial, with numerous conflicting opinions on the utility of endoscopic therapies to manage GERD. While there is evidence that they provide some degree of relief from GERD, they remain second-line to surgical intervention. ${ }^{135}$ More research is required at this time to better demonstrate the long-term outcomes of these interventions.

\section{Conclusion}

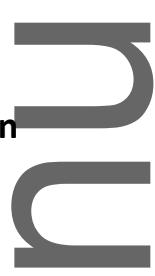

A thorough assessment of patients with PPI refractory GERD is important in assessing the most effective therapy for patients and also to exclude alternative pathology (eg: esophageal dysmotility or delayed gastric emptying). A recent trial has shown antireflux surgery has greater improvement in quality of life when compared with medication alone, however, a secondary finding was that a large number of patients being considered for these interventions either do not have GERD or have conditions not amenable to treatment by either medical therapy or surgery. ${ }^{56,131}$ As such, although a thorough clinical history and trial of pharmacological measures in the first instance are important, a comprehensive workup with more invasive testing is vital in appreciating the true underlying pathophysiological cause of each patient's disease process. With numerous investigations available, an understanding of the factors contributing to the patient's GERD enables clinicians to utilize appropriate therapeutic strategies. GERD is a complex cluster of phenotypes. A more nuanced approach is important in the investigation and treatment of GERD through a deeper understanding of the pathophysiology of the disease, the strengths and limitations of investigations, and the specific targets or mechanisms of each available therapy. The proper assessment might include a broader interpretation of $\mathrm{pH} /$ manometry data, meticulous dynamic endoscopic evaluation before nonmedical therapies, and proper patient selection for antireflux procedures. The step-wise approach from lifestyle modification to medical therapy to surgery can overlook the complexity of

This article is protected by copyright. All rights reserved. 
the disease and lead to suboptimal management. Proper workup and in-depth consideration of the underlying process on a case-by-case basis is necessary to properly tailor the best therapy.

\section{Competinginterests:}

H.M. H.B. and S.B. declare no competing interests. M.R. is the recipient of the Senior Lecturer Fellowship from the Royal Australasian College of Surgeons.

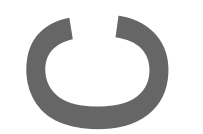

References

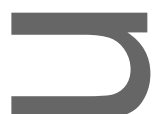

1. Eusebi LH, Ratnakumaran R, Yuan Y, Solaymani-Dodaran M, Bazzoli F, Ford AC. Global prevalence of, and risk factors for, gastro-oesophageal reflux symptoms: a meta-analysis. Gut. 2018;67(3):430-40.

2. Katz PO, Gerson LB, Vela MF. Guidelines for the diagnosis and management of gastroesophageal reflux disease. The American journal of gastroenterology. 2013;108(3):308-28; quiz 29.

3. Boeckxstaens GE, Rohof WO. Pathophysiology of gastroesophageal reflux disease. Gastroenterology clinics of North America. 2014;43(1):15-25.

4. Naini BV, Souza RF, Odze RD. Barrett's Esophagus: A Comprehensive and Contemporary Review for Pathologists. Am J Surg Pathol. 2016;40(5):e45-e66.

5. Frazzoni M, Piccoli M, Conigliaro R, Frazzoni L, Melotti G. Laparoscopic fundoplication for gastroesophageal reflux disease. World J Gastroenterol. 2014;20(39):14272-9.

6. YachimskiP. Modifiable Risk Factors for Barrett's Esophagus and Esophageal Adenocarcinoma: Still a Shot in the Dark. Clinical gastroenterology and hepatology : the official clinical practice journal of the American Gastroenterological Association. 2016;14(5):773-4.

7. Katzka DA, Pandolfino JE, Kahrilas PJ. Phenotypes of Gastroesophageal Reflux Disease: Where Rome, Lyon, and Montreal Meet. Clinical gastroenterology and hepatology : the official clinical practice journal of the American Gastroenterological Association. 2020;18(4):767-76.

8. Vakil N, van Zanten SV, Kahrilas P, Dent J, Jones R. The Montreal definition and classification of gastroesophageal reflux disease: a global evidence-based consensus. The American journal of gastroenterology. 2006;101(8):1900-20; quiz 43.

This article is protected by copyright. All rights reserved. 
9. Savarino E, Bredenoord AJ, Fox M, Pandolfino JE, Roman S, Gyawali CP. Expert consensus document: Advances in the physiological assessment and diagnosis of GERD. Nature reviews Gastroenterology \& hepatology. 2017;14(11):665-76.

10. Gyawali CP, Kahrilas PJ, Savarino E, Zerbib F, Mion F, Smout A, et al. Modern diagnosis of GERD: the Lyon Consensus. Gut. 2018;67(7):1351-62.

11. Menezes MA, Herbella FAM. Pathophysiology of Gastroesophageal Reflux Disease. World journal of surgery. 2017;41(7):1666-71.

12. De Giorgi F, Palmiero M, Esposito I, Mosca F, Cuomo R. Pathophysiology of gastrooesophageal reflux disease. Acta Otorhinolaryngol Ital. 2006;26(5):241-6.

13. Osadchiy Martin CR, Mayer EA. The Gut-Brain Axis and the Microbiome: Mechanisms and Clinical Implications. Clinical gastroenterology and hepatology : the official clinical practice journal of the American Gastroenterological Association. 2019;17(2):322-32.

14. Hershcovici T, Mashimo H, Fass R. The lower esophageal sphincter. Neurogastroenterology \& Motility. 2011;23(9):819-30.

15. Goyal RK, Guo Y, Mashimo H. Advances in the physiology of gastric emptying. Neurogastroenterology and motility : the official journal of the European Gastrointestinal Motility Society. 2019;31(4):e13546.

16. Tack J, Pandolfino JE. Pathophysiology of Gastroesophageal Reflux Disease. Gastroenterology. 2018;154(2):277-88.

17. Findlay JM, Maynard ND. Pathophysiology and investigation of gastro-oesophageal reflux disease. In: Griffin MS, editor. Oesophagogastric Surgery: A Companion to Specialist Surgical Practice,: Elsevier; 2019.

18. Zifan A, Kumar D, Cheng LK, Mittal RK. Three-Dimensional Myoarchitecture of the Lower Esophageal Sphincter and Esophageal Hiatus Using Optical Sectioning Microscopy. Scientific Reports. 2017;7(1):13188

19. Sinnatamby CS. Last's Anatomy Regional and Applied. 12th ed: Elsevier; 2011.

20. LohsiriwatS, Puengna N, Leelakusolvong S. Effect of caffeine on lower esophageal sphincter pressure in Thai healthy volunteers. Diseases of the esophagus : official journal of the International Society forDiseases of the Esophagus. 2006;19(3):183-8.

21. Kohata Y, Fujiwara $\mathrm{Y}$, Watanabe $\mathrm{T}$, Kobayashi $\mathrm{M}$, Takemoto $\mathrm{Y}$, Kamata N, et al. Long-Term Benefits of Smoking Cessation on Gastroesophageal Reflux Disease and Health-Related Quality of Life. PLOSONE. 2016;11(2):e0147860.

22. Kahrilas PJ, Gupta RR. Mechanisms of acid reflux associated with cigarette smoking. Gut. 1990;31(1):4-10.

This article is protected by copyright. All rights reserved. 
23. Pan J, Cen L, Chen W, Yu C, Li Y, Shen Z. Alcohol Consumption and the Risk of Gastroesophageal Reflux Disease: A Systematic Review and Meta-analysis. Alcohol and alcoholism (Oxford, Oxfordshire). 2019;54(1):62-9.

24. Spence AD, Busby J, Murchie P, Kunzmann AT, McMenamin Ú C, Coleman HG, et al. Medications that relax the lower oesophageal sphincter and risk of oesophageal cancer: An analysis of two independent population-based databases. International journal of cancer. 2018;143(1):22-31.

25. Newberry C, Lynch K. The role of diet in the development and management of gastroesophageal reflux disease: why we feel the burn. J Thorac Dis. 2019;11(Suppl 12):S1594-S601.

26. Jacobson BC, Somers SC, Fuchs CS, Kelly CP, Camargo CA, Jr. Body-mass index and symptoms of gastroesophageal reflux in women. N Engl J Med. 2006;354(22):2340-8.

27. El-Serag HB, Graham DY, Satia JA, Rabeneck L. Obesity Is an Independent Risk Factor for GERD Symptoms and Erosive Esophagitis. Official journal of the American College of Gastroenterology ACG. 2005;100(6):1243-50.

28. Singh M, Lee J, Gupta N, Gaddam S, Smith BK, Wani SB, et al. Weight loss can lead to resolution of gastroesophageal reflux disease symptoms: a prospective intervention trial. Obesity (Silver Spring, Md). 2013;21(2):284-90.

29. Mercer CD, Rue C, Hanelin L, Hill LD. Effect of obesity on esophageal transit. American journal of surgery.1985;149(1):177-81.

30. Pandolfino JE, El-Serag HB, Zhang Q, Shah N, Ghosh SK, Kahrilas PJ. Obesity: a challenge to esophagogastric junction integrity. Gastroenterology. 2006;130(3):639-49.

31. de Mello Del Grande L, Herbella FAM, Katayama RC, Lima WG, Patti MG. Transdiaphragmatic Pressure Gradient (TPG) Has a Central Role in the Pathophysiology of Gastroesophageal Reflux Disease (GERD) in the Obese and it Correlates with Abdominal Circumference but Not with Body Mass Index (BMI). Obesity surgery. 2020;30(4):1424-8.

32. Che F, Nguyen B, Cohen A, Nguyen NT. Prevalence of hiatal hernia in the morbidly obese. Surgery for obesity and related diseases : official journal of the American Society for Bariatric Surgery. 2013;9(6):920-4.

33. Wilson LJ, Ma M.S W, Hirschowitz BI. Association of obesity with hiatal hernia and esophagitis. The American journal of gastroenterology. 1999;94(10):2840-4.

34. Khan M, Mukherjee AJ. Hiatal hernia and morbid obesity-'Roux-en-Y gastric bypass' the one step solution. J Surg Case Rep. 2019;2019(6):rjz189-rjz.

35. WUJCY, Mui LM, Cheung CMY, Chan Y, Sung JJY. Obesity Is Associated With Increased Transient LowerEsophageal Sphincter Relaxation. Gastroenterology. 2007;132(3):883-9.

This article is protected by copyright. All rights reserved. 
36. Nebel OT, Castell DO. Inhibition of the lower oesophageal sphincter by fat--a mechanism for fatty food intolerance. Gut. 1973;14(4):270-4.

37. Fox M, Barr C, Nolan S, Lomer M, Anggiansah A, Wong T. The effects of dietary fat and calorie density on esophageal acid exposure and reflux symptoms. Clinical gastroenterology and hepatology : the official clinical practice journal of the American Gastroenterological Association. 2007;5(4):439-44

38. Valipour A, Makker HK, Hardy R, Emegbo S, Toma T, Spiro SG. Symptomatic gastroesophageal reflux in subjects with a breathing sleep disorder. Chest. 2002;121(6):1748-53.

39. Ing AJ, Ngu MC, Breslin ABX. Obstructive sleep apnea and gastroesophageal reflux. The American Journal of Medicine. 2000;108(4):120-5.

40. Abdelkader NA, Montasser IF, Bioumy EE, Saad WE. Impact of anthropometric measures and serum leptin on severity of gastroesophageal reflux disease. Diseases of the esophagus : official journal of the International Society for Diseases of the Esophagus. 2015;28(7):691-8.

41. Rubenstein JH, Morgenstern H, McConell D, Scheiman JM, Schoenfeld P, Appelman $\mathrm{H}$, et al. Associations of diabetes mellitus, insulin, leptin, and ghrelin with gastroesophageal reflux and Barrett's esophagus. Gastroenterology. 2013;145(6):1237-44.e1-5.

42. Roman S, Holloway R, Keller J, Herbella F, Zerbib F, Xiao Y, et al. Validation of criteria for the definition of transient lower esophageal sphincter relaxations using high-resolution manometry. Neurogastroenterology and motility : the official journal of the European Gastrointestinal Motility Society. 2017;29(2)

43. Jiang Y, Sandler B, Bhargava V, Mittal RK. Antireflux action of Nissen fundoplication and stretch-sensitive mechanism of lower esophageal sphincter relaxation. Gastroenterology. 2011;140(2):442-9.

44. Kim CD, Goyal RK, Mashimo H. Neuronal NOS provides nitrergic inhibitory neurotransmitter in mouse lower esophageal sphincter. American Journal of Physiology-Gastrointestinal and Liver Physiology. 1999;277(2):G280-G4.

45. Lehmann A, Antonsson $M$, Bremner-Danielsen $M$, Flärdh $M$, Hansson-Brändén $L$, Kärrberg L. Activation of the $G A B A(B)$ receptor inhibits transient lower esophageal sphincter relaxations in dogs. Gastroenterology. 1999;117(5):1147-54.

46. Hill LD, Kozarek RA, Kraemer SJM, Aye RW, Mercer CD, Low DE, et al. The gastroesophageal flap valve: in vitro and in vivo observations. Gastrointestinal Endoscopy. 1996;44(5):541-7.

47. Kim GH, Kang DH, Song GA, Kim TO, Heo J, Cho M, et al. Gastroesophageal flap valve is associated with gastroesophageal and gastropharyngeal reflux. Journal of gastroenterology. 2006;41(7):654-61.

This article is protected by copyright. All rights reserved. 
48. Quach DT, Nguyen TT, Hiyama T. Abnormal Gastroesophageal Flap Valve Is Associated With High Gastresophageal Reflux Disease Questionnaire Score and the Severity of Gastroesophageal Reflux Disease in Vietnamese Patients With Upper Gastrointestinal Symptoms. J Neurogastroenterol Motil. 2018;24(2):226-32.

49. Cheong JH, Kim GH, Lee BE, Choi MK, Moon JY, Ryu DY, et al. Endoscopic grading of gastroesophageal flap valve helps predict proton pump inhibitor response in patients with gastroesophageal reflux disease. Scandinavian journal of gastroenterology. 2011;46(7-8):789-96.

50. Koch OO, Spaun G, Antoniou SA, Rabl C, Köhler G, Emmanuel K, et al. Endoscopic grading of the gastroesophageal flap valve is correlated with reflux activity and can predict the size of the esophageal hiatus in patients with gastroesophageal reflux disease. Surgical endoscopy. 2013;27(12):4590-5.

51. HillLD, Kozarek RA. The Gastroesophageal Flap Valve. Journal of clinical gastroenterology. 1999;28(3):194

52. Ott DJ, Gelfand DW, Chen YM, Wu WC, Munitz HA. Predictive relationship of hiatal hernia to reflux esophagitis. Gastrointestinal radiology. 1985;10(4):317-20.

53. OttDJ, Glauser SJ, Ledbetter MS, Chen MY, Koufman JA, Gelfand DW. Association of hiatal hernia and gastroesophageal reflux: correlation between presence and size of hiatal hernia and 24hour pH monitoring of the esophagus. AJR American journal of roentgenology. 1995;165(3):557-9.

54. Kahrilas PJ, McColl K, Fox M, O'Rourke L, Sifrim D, Smout AJPM, et al. The Acid Pocket: A Target for Treatment in Reflux Disease? American Journal of Gastroenterology. 2013;108(7).

55. Beaumont H, Bennink RJ, de Jong J, Boeckxstaens GE. The position of the acid pocket as a major risk factor for acidic reflux in healthy subjects and patients with GORD. Gut. 2010;59(4):441.

56. Spechler SJ, Hunter JG, Jones KM, Lee R, Smith BR, Mashimo H, et al. Randomized Trial of Medical versus Surgical Treatment for Refractory Heartburn. New England Journal of Medicine. 2019;381(16):1513-23.

57. Hatlebakk JG, Katz PO, Kuo B, Castell DO. Nocturnal gastric acidity and acid breakthrough on different regimens of omeprazole $40 \mathrm{mg}$ daily. Alimentary pharmacology \& therapeutics. 1998;12(12):1235-40.

58. Pace $F$, Pace $M$. The proton pump inhibitor test and the diagnosis of gastroesophageal reflux disease. Expert review of gastroenterology \& hepatology. 2010;4(4):423-7.

59. Gasiorowska A, Fass R. The proton pump inhibitor (PPI) test in GERD: does it still have a role? Journal of clinical gastroenterology. 2008;42(8):867-74.

This article is protected by copyright. All rights reserved. 
60. Hansdotter I, Björ O, Andreasson A, Agreus L, Hellström P, Forsberg A, et al. Hill classification is superior to the axial length of a hiatal hernia for assessment of the mechanical anti-reflux barrier at the gastroesophageal junction. Endoscopy international open. 2016;4(3):E311-7.

61. Vere CC, Cazacu S, Comănescu V, Mogoantă L, Rogoveanu I, Ciurea T. Endoscopical and histological features in bile reflux gastritis. Romanian journal of morphology and embryology = Revue roumaine de morphologie et embryologie. 2005;46(4):269-74.

62. McQuaid KR, Laine L, Fennerty MB, Souza R, Spechler SJ. Systematic review: the role of bile acids in the pathogenesis of gastro-oesophageal reflux disease and related neoplasia. Alimentary pharmacology \& therapeutics. 2011;34(2):146-65.

63. Labenz J, Tillenburg B, Peitz U, Börsch G, Idström JP, Verdú E, et al. Efficacy of omeprazole one year after cure of Helicobacter pylori infection in duodenal ulcer patients. The American journal of gastroenterology. 1997;92(4):576-81.

64. Rubenstein JH, Inadomi JM, Scheiman J, Schoenfeld P, Appelman H, Zhang M, et al. Association between Helicobacter pylori and Barrett's esophagus, erosive esophagitis, and gastroesophageal reflux symptoms. Clinical gastroenterology and hepatology : the official clinical practice journal of the American Gastroenterological Association. 2014;12(2):239-45.

65. Fischbach $L A$, Nordenstedt $H$, Kramer JR, Gandhi S, Dick-Onuoha S, Lewis A, et al. The association between Barrett's esophagus and Helicobacter pylori infection: a meta-analysis. Helicobacter. 2012;17(3):163-75.

66. Ward MA, Dunst CM, Teitelbaum EN, Halpin VJ, Reavis KM, Swanström LL, et al. Impedance$\mathrm{pH}$ monitoring on medications does not reliably confirm the presence of gastroesophageal reflux disease in patients referred for antireflux surgery. Surgical endoscopy. 2018;32(2):889-94.

67. Neto R, Herbella F, Schlottmann F, Patti M. Does DeMeester score still define GERD? Diseases of the Esophagus. 2018;32.

68. Trudgill NJ, Sifrim D, Sweis R, Fullard M, Basu K, McCord M, et al. British Society of Gastroenterology guidelines for oesophageal manometry and oesophageal reflux monitoring. Gut. 2019;68(10);1731-50.

69. Taghavi SA, Ghasedi M, Saberi-Firoozi M, Alizadeh-Naeeni M, Bagheri-Lankarani K, Kaviani $\mathrm{MJ}$, et at Symptom association probability and symptom sensitivity index: preferable but still suboptima| predictors of response to high dose omeprazole. Gut. 2005;54(8):1067-71.

70. Kahrilas PJ, Bredenoord AJ, Fox M, Gyawali CP, Roman S, Smout AJ, et al. The Chicago Classification of esophageal motility disorders, v3.0. Neurogastroenterology and motility : the official journal of the European Gastrointestinal Motility Society. 2015;27(2):160-74.

71. Bredenoord AJ, Fox M, Kahrilas PJ, Pandolfino JE, Schwizer W, Smout AJ. Chicago classification criteria of esophageal motility disorders defined in high resolution esophageal pressure

This article is protected by copyright. All rights reserved. 
topography. Neurogastroenterology and motility : the official journal of the European Gastrointestinal Motility Society. 2012;24 Suppl 1(Suppl 1):57-65.

72. Schlottmann F, Herbella FA, Patti MG. Understanding the Chicago Classification: From Tracings to Patients. J Neurogastroenterol Motil. 2017;23(4):487-94.

73. Jung DH, Park H. Is Gastroesophageal Reflux Disease and Achalasia Coincident or Not? J Neurogastroenterol Motil. 2017;23(1):5-8.

74. Kimmel JN, Carlson DA, Hinchcliff M, Carns MA, Aren KA, Lee J, et al. The association between systemic sclerosis disease manifestations and esophageal high-resolution manometry parameters. Neurogastroenterology and motility : the official journal of the European Gastrointestinal Motility Society. 2016;28(8):1157-65.

75. Gyawali CP, de Bortoli N, Clarke J, Marinelli C, Tolone S, Roman S, et al. Indications and interpretation of esophageal function testing. Annals of the New York Academy of Sciences. 2018;1434(1):239-53.

76. Saleh CM, Smout AJ, Bredenoord AJ. The diagnosis of gastro-esophageal reflux disease cannot be made with barium esophagograms. Neurogastroenterology and motility : the official journal of the European Gastrointestinal Motility Society. 2015;27(2):195-200.

77. Saad RJ, Hasler WL. A technical review and clinical assessment of the wireless motility capsule. Gastroenterol Hepatol (N Y). 2011;7(12):795-804.

78. Bharucha AE, Camilleri M, Veil E, Burton D, Zinsmeister AR. Comprehensive assessment of gastric emptying with a stable isotope breath test. Neurogastroenterology and motility : the official journal of the European Gastrointestinal Motility Society. 2013;25(1):e60-e9.

79. Maradey C, Fass R. GERD: Surgery or medical therapy for patients with GERD? Nature reviews Gastroenterology \& hepatology. 2013;10(8):448-9.

80. Sandhu DS, Fass R. Current Trends in the Management of Gastroesophageal Reflux Disease. Gut and liver. 2018,12(1):7-16.

81. Zarzour JG, Morgan DE, Callaway JP, Hawn MT, Canon CL, Koehler RE. Anti-reflux procedures: complications, radiologic findings, and surgical and gastroenterologic perspectives. Abdominal radiology (New York). 2018;43(6):1308-18.

82. Park SK, Lee T, Yang HJ, Park JH, Sohn Cl, Ryu S, et al. Weight loss and waist reduction is associated with improvement in gastroesophageal disease reflux symptoms: A longitudinal study of 15295 subjects undergoing health checkups. Neurogastroenterology and motility : the official journal of the European Gastrointestinal Motility Society. 2017;29(5).

This article is protected by copyright. All rights reserved. 
83. Nowak M, Büttner P, Raasch B, Daniell K, McCutchan C, Harrison S. Lifestyle changes as a treatment of gastroesophageal reflux disease: a survey of general practitioners in North Queensland, Australia. Ther Clin Risk Manag. 2005;1(3):219-24.

84. Kaltenbach T, Crockett S, Gerson LB. Are Lifestyle Measures Effective in Patients With Gastroesophageal Reflux Disease?: An Evidence-Based Approach. Archives of Internal Medicine. 2006;166(9):965-71.

85. Gyawali CP, Fass R. Management of Gastroesophageal Reflux Disease. Gastroenterology. 2018;154(2):302-18.

86. Subramanian CR, Triadafilopoulos G. Refractory gastroesophageal reflux disease. Gastroenterol Rep (Oxf). 2015;3(1):41-53.

87. Pace F, Sangaletti O, Pallotta S, Molteni P, Porro GB. Biliary reflux and non-acid reflux are two distinct phenomena: a comparison between 24-hour multichannel intraesophageal impedance and bilirubin monitoring. Scandinavian journal of gastroenterology. 2007;42(9):1031-9.

88. Sarkany RPE, Moreland BH. Enhancement of the autocatalytic activation of trypsinogen to trypsin by bile and bile acids. Biochimica et Biophysica Acta (BBA) - General Subjects. $1985 ; 839(3): 262-7$.

89. Fass R, Sifrim D. Management of heartburn not responding to proton pump inhibitors. Gut. 2009;58(2):295-309.

90. Kinoshita Y, Ishimura N, Ishihara S. Advantages and Disadvantages of Long-term Proton Pump Inhibitor Use. J Neurogastroenterol Motil. 2018;24(2):182-96.

91. Fossmark R, Martinsen TC, Waldum HL. Adverse Effects of Proton Pump Inhibitors-Evidence and Plausibility. Int J Mol Sci. 2019;20(20):5203.

92. Bouziana SD, Tziomalos K. Clinical relevance of clopidogrel-proton pump inhibitors interaction. World J Gastrointest Pharmacol Ther. 2015;6(2):17-21.

93. Evanchan J, Donnally MR, Binkley P, Mazzaferri E. Recurrence of Acute Myocardial Infarction in Patients Discharged on Clopidogrel and a Proton Pump Inhibitor After Stent Placement for Acute Myocardial Infarction. Clinical Cardiology. 2010;33(3):168-71.

94. Khan SU, Lone AN, Asad ZUA, Rahman H, Khan MS, Saleem MA, et al. Meta-Analysis of Efficacy and Safety of Proton Pump Inhibitors with Dual Antiplatelet Therapy for Coronary Artery Disease. Cardiovasgular Revascularization Medicine. 2019;20(12):1125-33.

95. Sigterman KE, van Pinxteren B, Bonis PA, Lau J, Numans ME. Short-term treatment with proton pump inhibitors, $\mathrm{H} 2$-receptor antagonists and prokinetics for gastro-oesophageal reflux disease-like symptoms and endoscopy negative reflux disease. The Cochrane database of systematic reviews. 2013;2013(5):Cd002095.

This article is protected by copyright. All rights reserved. 
96. Fackler WK, Ours TM, Vaezi MF, Richter JE. Long-term effect of H2RA therapy on nocturnal gastric acid breakthrough. Gastroenterology. 2002;122(3):625-32.

97. De Ruigh A, Roman S, Chen J, Pandolfino JE, Kahrilas PJ. Gaviscon Double Action Liquid (antacid \& alginate) is more effective than antacid in controlling post-prandial oesophageal acid exposure in GERD patients: a double-blind crossover study. Alimentary pharmacology \& therapeutics. 2014;40(5):531-7.

98. Hampson FC, Farndale A, Strugala V, Sykes J, Jolliffe IG, Dettmar PW. Alginate rafts and their characterisation. International journal of pharmaceutics. 2005;294(1-2):137-47.

99. Leiman DA, Riff BP, Morgan S, Metz DC, Falk GW, French B, et al. Alginate therapy is effective treatment for GERD symptoms: a systematic review and meta-analysis. Diseases of the Esophagus. 2017;30(5):1-9.

100. Clarke JO, Fernandez-Becker NQ, Regalia KA, Triadafilopoulos G. Baclofen and gastroesophageal reflux disease: seeing the forest through the trees. Clin Transl Gastroenterol. 2018;9(3):

101. Blondeau K, Boecxstaens V, Rommel N, Farré R, Depeyper S, Holvoet L, et al. Baclofen improves symptoms and reduces postprandial flow events in patients with rumination and supragastric belching. Clinical gastroenterology and hepatology : the official clinical practice journal of the American Gastroenterological Association. 2012;10(4):379-84.

102. Warren RL, Davis SM. The Role of Baclofen in the Treatment of Gastroesophageal Reflux Disease. J Pharm Technol. 2015;31(6):258-61.

103. Vaezi MF, Fass R, Vakil N, Reasner DS, Mittleman RS, Hall M, et al. IW-3718 Reduces Heartburn Severity in Patients With Refractory Gastroesophageal Reflux Disease in a Randomized Trial. Gastroenterology. 2020.

104. Holzer P.Acid-sensing ion channels in gastrointestinal function. Neuropharmacology. 2015;94:72-9.

105. Swanstrom LL, Jobe BA, Kinzie LR, Horvath KD. Esophageal motility and outcomes following laparoscopic paraesophageal hernia repair and fundoplication. American journal of surgery. 1999;177(5):359-63.

106. Galmiche JP, Hatlebakk J, Attwood S, Ell C, Fiocca R, Eklund S, et al. Laparoscopic antireflux surgery vs esomeprazole treatment for chronic GERD: the LOTUS randomized clinical trial. Jama. 2011;305(19):1969-77.

107. Pauwels A, Boecxstaens V, Andrews CN, Attwood SE, Berrisford R, Bisschops R, et al. How to select patients for antireflux surgery? The ICARUS guidelines (international consensus regarding preoperative examinations and clinical characteristics assessment to select adult patients for antireflux surgery). Gut. 2019;68(11):1928.

This article is protected by copyright. All rights reserved. 
108. Marshall-Webb M, Peters MDJ, Bright T, Watson DI. Effectiveness of Nissen fundoplication versus anterior and posterior partial fundoplications for treatment of gastro-esophageal reflux disease: a systematic review protocol. JBI database of systematic reviews and implementation reports. 2018;16(5):1095-102.

109. Andreou A, Watson DI, Mavridis D, Francis NK, Antoniou SA. Assessing the efficacy and safety of laparoscopic antireflux procedures for the management of gastroesophageal reflux disease: a systematic review with network meta-analysis. Surgical endoscopy. 2020;34(2):510-20.

110. Herbella FAM, Schlottmann F, Patti MG. Pathophysiology of gastroesophageal reflux disease: how an antireflux procedure works (or does not work). Updates in surgery. 2018;70(3):343-7.

111. Ravi N, Al-Sarraf N, Balfe P, Byrne PJ, Reynolds JV. On-table endoscopy following laparoscopic fundoplication. Journal of gastrointestinal surgery : official journal of the Society for Surgery of the Alimentary Tract. 2008;12(6):991-6.

112. Ata-Lawenko RM, Lee YY. Emerging Roles of the Endolumenal Functional Lumen Imaging Probe in Gastrointestinal Motility Disorders. J Neurogastroenterol Motil. 2017;23(2):164-70.

113. Bashir Y, Chonchubhair HN, Duggan SN, Memba R, Ain QU, Murphy A, et al. Systematic review and meta-analysis on the effect of obesity on recurrence after laparoscopic anti-reflux surgery. The surgeon : journal of the Royal Colleges of Surgeons of Edinburgh and Ireland. 2019;17(2):107-18.

114. El-Hadi M, Birch DW, Gill RS, Karmali S. The effect of bariatric surgery on gastroesophageal reflux disease. Canadian journal of surgery Journal canadien de chirurgie. 2014;57(2):139-44.

115. Azagury D, Morton J. Surgical Anti-Reflux Options Beyond Fundoplication. Current gastroenterology reports. 2017;19(7):35.

116. Ashrafi D, Osland E, Memon MA. Bariatric surgery and gastroesophageal reflux disease. Annals of translational medicine. 2020;8(Suppl 1):S11.

117. Bonavina L, DeMeester TR, Ganz RA. LINX() Reflux Management System: magnetic sphincter augmentation in the treatment of gastroesophageal reflux disease. Expert review of gastroenterology \& hepatology. 2012;6(6):667-74.

118. Schizas D, Mastoraki A, Papoutsi E, Giannakoulis VG, Kanavidis P, Tsilimigras D, et al. LINX( $\left.{ }^{\oplus}\right)$ reflux management system to bridge the "treatment gap" in gastroesophageal reflux disease: $\mathrm{A}$ systematic review of 35 studies. World J Clin Cases. 2020;8(2):294-305.

119. Buckley FP, Havemann B, Chawla A. Magnetic sphincter augmentation: Optimal patient selection and referral care pathways. World journal of gastrointestinal endoscopy. 2019;11(8):472-6.

This article is protected by copyright. All rights reserved. 
120. Richards WO, McRae C. Comparative Analysis of Laparoscopic Fundoplication and Magnetic Sphincter Augmentation for the Treatment of Medically Refractory GERD. The American surgeon. 2018;84(11):1762-7.

121. Bauer $M$, Meining A, Kranzfelder $M$, Jell A, Schirren R, Wilhelm D, et al. Endoluminal perforation of a magnetic antireflux device. Surgical endoscopy. 2015;29(12):3806-10.

122. Reynolds لL, Zehetner J, Wu P, Shah S, Bildzukewicz N, Lipham JC. Laparoscopic Magnetic Sphincter Augmentation vs Laparoscopic Nissen Fundoplication: A Matched-Pair Analysis of 100 Patients. Journal of the American College of Surgeons. 2015;221(1):123-8.

123. Stephan D, Attwood S, Labenz J, Willeke F. [EndoStim ${ }^{\circledR}$ treatment-a new minimally invasive technology in antireflux surgery]. Der Chirurg; Zeitschrift fur alle Gebiete der operativen Medizen. 2018;89(10):785-92.

124. Hoppo T, Rodríguez L, Soffer E, Crowell MD, Jobe BA. Long-term results of electrical stimulation of the lower esophageal sphincter for treatment of proximal GERD. Surgical endoscopy. 2014;28(12):3293-301.

125. Franciosa M, Triadafilopoulos G, Mashimo H. Stretta Radiofrequency Treatment for GERD: A Safe and Effective Modality. Gastroenterology research and practice. 2013;2013:783815.

126. Fass R, Cahn F, Scotti DJ, Gregory DA. Systematic review and meta-analysis of controlled and prospective cohort efficacy studies of endoscopic radiofrequency for treatment of gastroesophageal reflux disease. Surgical endoscopy. 2017;31(12):4865-82.

127. Perry KA, Banerjee A, Melvin WS. Radiofrequency energy delivery to the lower esophageal sphincter reduces esophageal acid exposure and improves GERD symptoms: a systematic review and meta-analysis. Surgical laparoscopy, endoscopy \& percutaneous techniques. 2012;22(4):283-8.

128. Sami Trad K. Transoral incisionless fundoplication: current status. Current opinion in gastroenterology. 2016;32(4):338-43.

129. LipkaS, Kumar A, Richter JE. No Evidence for Efficacy of Radiofrequency Ablation for Treatment of Gastroesophageal Reflux Disease: A Systematic Review and Meta-Analysis. Clinical Gastroenterology and Hepatology. 2015;13(6):1058-67.e1.

130. Funk LM, Zhang JY, Drosdeck JM, Melvin WS, Walker JP, Perry KA. Long-term costeffectiveness of medical, endoscopic and surgical management of gastroesophageal reflux disease. Surgery. 2015;157(1):126-36.

131. Noar $M$, Squires $P$, Noar $E$, Lee $M$. Long-term maintenance effect of radiofrequency energy delivery for refractory GERD: a decade later. Surgical endoscopy. 2014;28(8):2323-33.

132. Lo WK, Mashimo H. Critical Assessment of Endoscopic Techniques for Gastroesophageal Reflux Disease. Journal of clinical gastroenterology. 2015;49(9):720-4.

This article is protected by copyright. All rights reserved. 
133. Nabi Z, Reddy DN. Endoscopic Management of Gastroesophageal Reflux Disease: Revisited. Clin Endosc. 2016;49(5):408-16.

134. YooIK, ChOJY. Endoscopic Treatment of Refractory Gastroesophageal Reflux Disease. In: Chun HJ, Yang S-K, Choi M-G, editors. Therapeutic Gastrointestinal Endoscopy: A Comprehensive Atlas. Singapore: Springer Singapore; 2019. p. 395-406.

135. Hopkins J, Switzer NJ, Karmali S. Update on novel endoscopic therapies to treat gastroesophageal reflux disease: A review. World journal of gastrointestinal endoscopy. 2015;7(11):1039-44.

136. Ren LH, Chen WX, Qian LJ, Li S, Gu M, Shi RH. Addition of prokinetics to PPI therapy in gastroesophageal reflux disease: a meta-analysis. World J Gastroenterol. 2014;20(9):2412-9.

137. Dallemagne B, Weerts J, Markiewicz S, Dewandre JM, Wahlen C, Monami B, et al. Clinical results of laparoscopic fundoplication at ten years after surgery. Surgical endoscopy. 2006;20(1):15965.

138. Oor JE, Broeders JA, Roks DJ, Oors JM, Weusten BL, Bredenoord AJ, et al. Reflux and Belching after Laparoscopic 270 degree Posterior Versus 180 degree Anterior Partial Fundoplication. Journal of gastrointestinal surgery : official journal of the Society for Surgery of the Alimentary Tract. 2018;22(11):1852-60.

139. Staehelin A, Zingg U, Devitt PG, Esterman AJ, Smith L, Jamieson GG, et al. Preoperative factors predicting clinical outcome following laparoscopic fundoplication. World journal of surgery. 2014;38(6):1431-43.

140. Zerbib F, Sacher-Huvelin S, Coron E, Coffin B, Melchior C, Ponchon T, et al. Randomised clinical trial: oesophageal radiofrequency energy delivery versus sham for PPI-refractory heartburn. Alimentary pharmacology \& therapeutics.n/a(n/a).

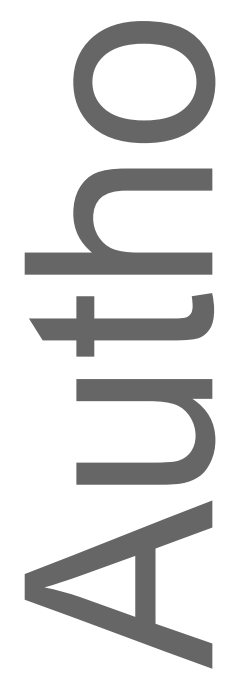

This article is protected by copyright. All rights reserved. 
Table 1. Summary of factors responsible for the pathophysiology of GERD ${ }^{13-16}$

\begin{tabular}{|c|c|c|c|}
\hline Intrinsic & Extrinsico & Physiologicalo & Secretoryo \\
\hline $\begin{aligned} & \bullet \rightarrow \text { The lower } \\
& \text { esophageal. } \\
& \text { sphincter } \\
& \bullet \rightarrow \text { Esophageal } \\
& \text { permeabilityo }\end{aligned}$ & 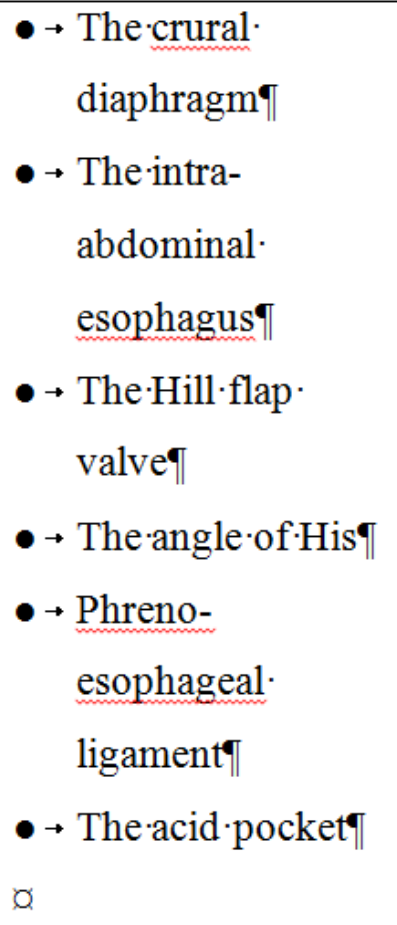 & 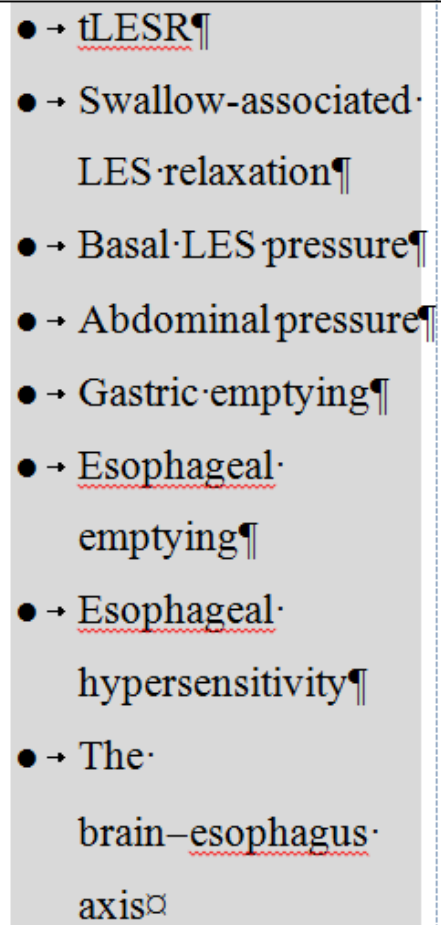 & 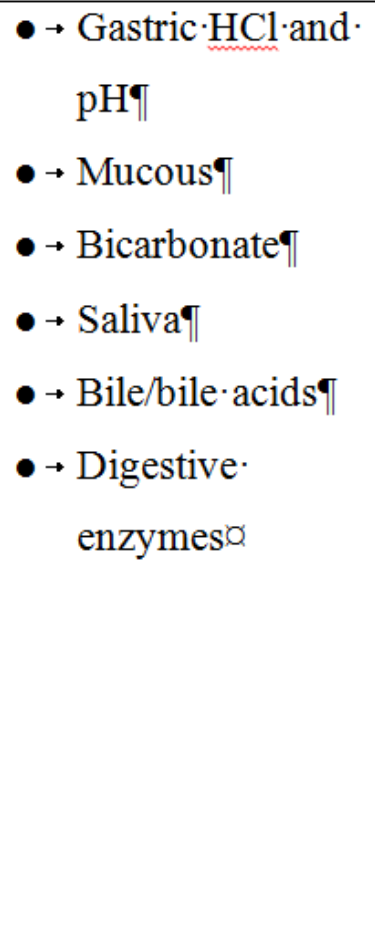 \\
\hline
\end{tabular}

Table 2. Gastroesophageal flap valve (Hill) classification ${ }^{46,51}$

\begin{tabular}{|l|l|l|}
\hline Hill flap grade & Description & \\
\hline I & A prominent fold of tissue originating at the angle of & \\
II & "His" in close apposition with the lesser curve and abuts & \\
& the endoscope & Normal \\
\hline III & $\begin{array}{l}\text { The fold of tissue present with an intermittent rapid } \\
\text { period of opening around the endoscope with }\end{array}$ & \\
\hline IV & $\begin{array}{l}\text { respiration } \\
\text { The fold is not prominent and the endoscope is not }\end{array}$ & \\
\hline & $\begin{array}{l}\text { gripped tightly by the ridge } \\
\text { An absent fold, the esophageal lumen gapes widely }\end{array}$ & \\
\hline & $\begin{array}{l}\text { open, and the esophageal mucosa visible from below } \\
\text { IV }\end{array}$ & \\
\hline
\end{tabular}

This article is protected by copyright. All rights reserved. 
Table 3. Therapeutic options in the treatment of GERD, mechanism, and evidence

\begin{tabular}{|c|c|c|}
\hline Therapy & Mechanism & Efficacy \\
\hline \multicolumn{3}{|l|}{ Lifestyle } \\
\hline $\begin{array}{l}\text { Lifestyle } \\
\text { modification }\end{array}$ & $\begin{array}{l}\text { Risk factor avoidance, dietary modification, } \\
\text { and head-of-bed-elevation }{ }^{84}\end{array}$ & $\begin{array}{l}\text { Poor evidence that lifestyle } \\
\text { changes have a significant } \\
\text { impact on GERD symptoms }\end{array}$ \\
\hline Weight loss & $\begin{array}{l}\text { Reduces intra-abdominal pressure in } \\
\text { abdominal or generally obese patients }\end{array}$ & $\begin{array}{l}\text { Improves GERD symptoms but not } \\
\text { esophagitis }\end{array}$ \\
\hline \multicolumn{3}{|l|}{ Medical Management } \\
\hline PPI & $\begin{array}{l}\text { Gastric acid secretion suppression by } \\
\text { irreversible blockade of } \mathrm{H}^{+-} \mathrm{K}^{+-} \text {ATPase } \\
\text { proton pumps }\end{array}$ & $\begin{array}{l}\text { Symptomatic relief in } 57 \% \text { to } 80 \% \\
\text { of patients with NERD } \\
\text { EE healing in } 85 \% \text { of patients }\end{array}$ \\
\hline $\mathrm{H}_{2} \mathrm{RA}$ & $\begin{array}{l}\text { Gastric acid secretion suppression by } \\
\text { competitive histamine receptor } \\
\text { blockade }^{85}\end{array}$ & $\begin{array}{l}\text { EE healing } 41 \% \text { of patients, } \\
\text { symptomatic resolution } 48 \text { to } \\
56 \% \text { of patients }\end{array}$ \\
\hline GABA ago & Reduction of tLESRs ${ }^{102}$ & $\begin{array}{l}\text { Reduces number reflux episodes } \\
\text { with central side effects }\end{array}$ \\
\hline Antacids & Acid neutralization & $\begin{array}{l}\text { Short term symptomatic relief, no } \\
\text { long-term symptomatic relief } \\
\text { of EE healing }\end{array}$ \\
\hline Prokinetic agent & $\begin{array}{l}\text { Increase LES tone and accelerate gastric } \\
\quad \text { emptying }^{85}\end{array}$ & $\begin{array}{l}\text { A modest reduction in symptoms } \\
\text { when given } \mathrm{PPI}^{136}\end{array}$ \\
\hline $\begin{array}{l}\text { Coleseve } \\
\text { (IW-37) }\end{array}$ & $\begin{array}{l}\text { Colesevelam. Sequestration of bile in the } \\
\text { stomach to reduce bile exposure to the } \\
\text { esophagus }\end{array}$ & $\begin{array}{l}\text { Improved heartburn and } \\
\text { regurgitation symptoms when } \\
\text { combined with } \mathrm{PPI} .{ }^{103}\end{array}$ \\
\hline \multicolumn{3}{|l|}{ Surgical management } \\
\hline Fundoplication & $\begin{array}{l}\text { Restoration of GEJ anatomy, reduction of } \mathrm{HH} \text {, } \\
\text { mechanical esophageal compression, and } \\
\text { reduction in LES relaxation triggering }\end{array}$ & $\begin{array}{l}90 \% \text { of patients are symptom-free } \\
\text { at } 10 \text { years, }{ }^{137} 60 \% \text { off PPI at } \\
17 \text { years. }{ }^{138} \text { Better outcomes } \\
\text { for those with HH preop. } \\
\text { Superior durability with Nissen } \\
\text { over partial but higher } \\
\text { dysphagia rate. }^{108} \text { Superior to } \\
\text { optimized medical therapy in a } \\
\text { select population of } \\
\text { treatment-refractory }_{\text {patients }}^{56}\end{array}$ \\
\hline
\end{tabular}

This article is protected by copyright. All rights reserved. 


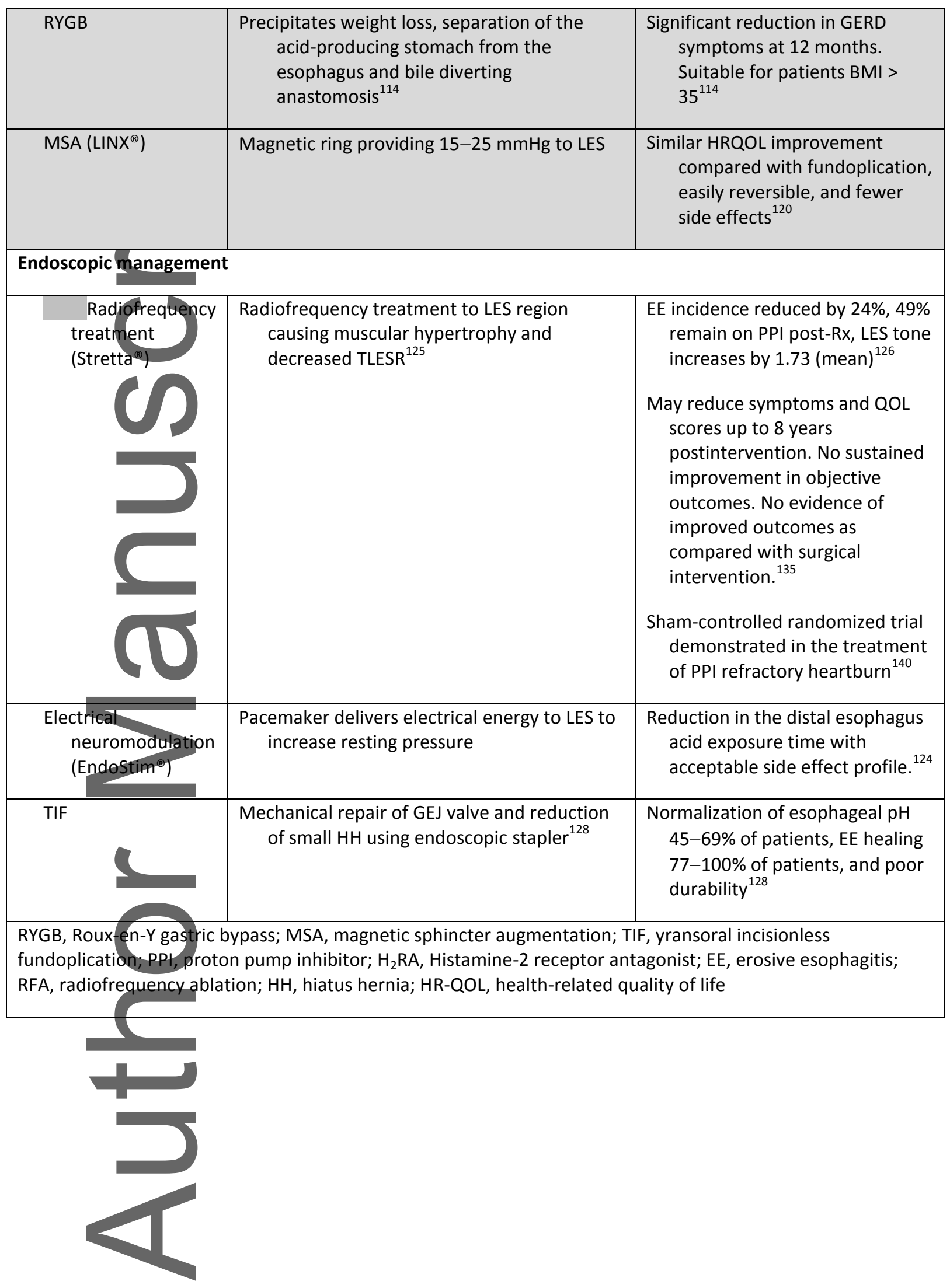

This article is protected by copyright. All rights reserved. 


\section{University Library}

\section{- M M I E E R VA A gateway to Melbourne's research publications}

Minerva Access is the Institutional Repository of The University of Melbourne

\section{Author/s:}

Banting, SP;Badgery, HE;Read, M;Mashimo, H

Title:

Rethinking gastroesophageal reflux disorder.

Date:

2020-12

Citation:

Banting, S. P., Badgery, H. E., Read, M. \& Mashimo, H. (2020). Rethinking gastroesophageal reflux disorder.. Ann N Y Acad Sci, 1482 (1), pp.177-192. https://doi.org/10.1111/ nyas. 14478.

Persistent Link:

http://hdl.handle.net/11343/276217 